\title{
Pengujian Algoritma MTCNN (Multi-task Cascaded Convolutional Neural Network) untuk Sistem Pengenalan Wajah
}

\author{
Yovi Pratama, Marrylinteri Istoningtyas, Errissya Rasywir \\ Teknik Informatika, STIKOM Dinamika Bangsa, Jambi, Indonesia \\ Email: 1'yovi.pratama@gmail.com, ${ }^{2}$ marrylinteri.jurnal@gmail.com, ${ }^{3}$ errissya.rasywir@gmail.com
}

\begin{abstract}
Abstrak
Pengukuran kemiripan wajah atau pengecekan similaritas dilakukan dengan menggunakan fitur. Algoritma untuk mendeskripsi penciri wajah yang paling mutahir dan paling bagus untuk menghasilkan fitur adalah Deep Convolutional Neural Network (DCNNs). Berdasarkan hal tersebut, penelitian ini menggunakan MTCNN (Multi-task Cascaded Convolutional Neural Network) sebagai salah satu variasi dari metode DCNN. Dalam riset ini, kami membangun sebuat sistem riset untuk pengujian hasil dengan javascript. Mengingat banyak sekali kebutuhan yang berbasis mobile atau dapat dijalankan pada smartphone. Salah satunya adalah untuk mendukung fitur absen yang digunakan secara mobile seperti sistem pelaporan kinerja sales dan marketing ataupun anggota personil kepolisian yang biasa bekerja secara mobile. Dari hasil pengujian yang dilakukan secara otomatis menggunakan beberapa model variasi pengujian citra dataset Aberdeen sebanyak 60 citra dari 30 orang berbeda yang digunakan pada sistem riset pengenalan wajah menggunakan MTCNN dengan parameter citra yang mempengaruhi seperti variasi pencahayaan, variasi posisi objek, kemudian posisi yang diambil serta ekspresi wajah pada citra objek, sistem riset berhasil melakukan pengenalan wajah sebesar $100 \%$. Dengan demikian, nilai true positive berjumlah sama dengan jumlah data yang dites dan nilai true negative berjumlah nol.
\end{abstract}

Kata Kunci: Pengenalan, Wajah, MTCNN, Biometrik, Sistem

\begin{abstract}
Measurement of facial similarity or checking similarity is done using features. The algorithm for describing the most up-todate and best face features for generating features is Deep Convolutional Neural Network (DCNNs). Based on this, this study uses MTCNN (Multi-task Cascaded Convolutional Neural Network) as one variation of the DCNN method. In this research, we built a research system to test results with javascript. Given the many needs that are based on mobile or can be run on a smartphone. One of them is to support the absent feature that is used in a mobile manner such as the reporting system of sales and marketing performance or members of the police personnel who normally work on a mobile basis. From the results of the tests carried out automatically using several variation models testing the image of the Aberdeen dataset as many as 60 images from 30 different people used in the face recognition research system using MTCNN with influencing image parameters such as lighting variations, object position variations, then the position taken and expression face on the object image, the research system managed to do face recognition by $100 \%$. Thus, true positive values are equal to the amount of data tested and zero negative true values.
\end{abstract}

Keywords: Recognition, Face, MTCNN, Biometric, System

\section{PENDAHULUAN}

Pekerjaan riset mengenal wajah serta menganalisa wajah masih merupakan pekerjaan yang cukup menantang pada komputer visi dan pengolahan citra[1]. Dalam melakukan pengenalan, perlu dilakukan suatu tugas agar komputer bisa mengerti tentang wajah serta bagaimana mengambil informasi yang terdapat pada wajah[2]. Proses tersebut bisa saja dilakukan dengan membuat komputer menganalisis lokasi wajah sebagai objek, ekspresi, ciri, umur serta emosi, yang terpancar di wajah, dan beberapa informasi lainnya[1]. Banyak sekali penerapan manfaat yang diperoleh dari riset pengenalan wajah ini antara lain: pengenalan identitas dari seseorang, smart cars untuk mendeteksi pengemudinya mengantuk, identifikasi dalam video, auntentifikasi smartphone, transaksi dengan biometrik wajah [3], [4]. Secara umum dalam pekerjaan analisa citra wajah terdapat tiga langkah utama yakni menentukan lokasi wajah sebagai objek, kemudian menangkap fiducial point atau titik penting wajah dan mendeskripsikan penciri atau fitur objek wajah[5].

Dalam menentukan lokasi wajah sebagai objek biasanya digunakan algoritma pendeteksi untuk mendeteksi lokasi objek wajah pada citra dan gambar bergerak dalam variasi posisi, cahaya serta ukuran[3], [6], [7]. Tujuannya dari langkah ini adalah mengurangi daerah yang tidak ada hubungan dengan objek sehingga mengurangi tugas analisis dalam sistem. Saat ini banyak terdapat algoritma yang mampu mendeteksi beberapa wajah [5], [8], [9]. Kemudian, pekerjaan menangkap fiducial point atau titik penting wajah untuk menandakan posisi dimana fiducial objek[10], [11]. Seperti titik pusat mata, tepi mulut, hidung dan berbagai titik dengan ukuran jarak antara satu sama lain. Titik fiducial ini sangat penting menyeleksi bagian dari wajah [12], [13]. Selain itu titik fiducial ini dapat digunakan untuk transformasi posisi wajah seperti melakukan rotasi, menggeser posisi, refleksi dan mengubah skala wajah. Pada proses mendeskripsikan penciri atau fitur objek wajah biasanya metode digunakan untuk menghasilkan informasi wajah. Dari informasi tersebut dapat digunakan untuk menghitung kemiripan. Pengukuran kemiripan atau pengecekan similaritas dilakukan dengan menggunakan fitur. Beberapa Algoritma untuk mendeskripsi penciri wajah antara lain LBP (Local Binary Pattern), PCA(Principal Component Analysis), Mahalanobis distance, dan algoritma yang paling mutahir dan paling bagus untuk menghasilkan fitur adalah Deep 
Convolutional Neural Network (DCNNs) dengan berbagai macam variasinya. Berdasarkan hal tersebut, penelitian ini menggunakan salah satu variasi dari metode DCNN tersebut. Yakni menggunakan MTCNN (Multi-task Cascaded Convolutional Neural Network). Metode ini kami terapkan dengan membangun sebuat sistem riset untuk pengujian hasil. Bahasa yang digunakan adalah javascript dengan harapan fitur ini dapat diterapkan untuk melakukan pengenalan wajah secara mobile. Mengingat banyak sekali kebutuhan yang berbasis mobile atau dapat dijalankan pada smartphone. Salah satunya adalah untuk mendukung fitur absen yang digunakan secara mobile seperti sistem pelaporan kinerja sales dan marketing ataupun anggota personil kepolisian yang biasa bekerja secara mobile.

\section{METODE PENELITIAN}

\subsection{Analisis Masalah Dan Solusi MTCNN}

Pada tahap ini dilakukan analisis masalah dan solusi MTCNN (Multi-task Cascaded Convolutional Neural Network). Masalah yang diangkat pada penelitian ini adalah bagaimana hasil penerapan algortima MTCNN (Multitask Cascaded Convolutional Neural Network) pada pengenalan wajah. Sebagaimana yang disebutkan pada latar belakang bahwa pengenalan wajah yag otomatis dan akurat digunakan sebagai sistem absensi wajah.Pemilihan algoritma MTCNN (Multi-task Cascaded Convolutional Neural Network) ini didasarkan pada studi literatur bahwa metode ini merupakan metode baru dalam dunia kecerdasan buatan khususnya dalam pekerjaan pengolahan citra. Berdasarkan permasalahan tersebut, pada penelitian ini kami mencoba membangun sebuat sistem riset yang digunakan khusus untuk ujicoba data citra wajah dalama tugas melakukan pengenalan wajah. Diharapkan sistem yang dibangun mampu melakukan pengenalan wajah secara otomatis dengan algoritma MTCNN (Multi-task Cascaded Convolutional Neural Network).

\subsection{Data Untuk Proses Pengenalan Wajah dengan MTCNN}

Tahap ini dilakukan pengumpulan data untuk proses pengenalan wajah dengan MTCNN (Multi-task Cascaded Convolutional Neural Network). Pada penelitian ini digunakan dataset citra Aberdeen. Dataset ini berisi citra dengan indeks gambar wajah untuk pengambilan berikutnya. Gambar ini dibuat dengan beberapa kondisi. Variasiyang terdapat saat pengambilan wajah adalah pencahayaan, variasi sudut dan ukuran objek pengambilan sebanyak 100 data citra wajah.

\subsection{Analisis MTCNN (Multi-task Cascaded Convolutional Neural Network)}

Bagian ini merupakan bagian analisis algortima MTCNN (Multi-task Cascaded Convolutional Neural Network) menggunakan pengukuran jarak dengan menggunakan eucludian distance. Pada sistem riset yang dibangun untuk melakukan pengenalan wajah menggunakan Restnet 34 sebagai model jaringan neural network. Karena beragam pose, pencahayaan, dan pemandangan, deteksi wajah dan kalibrasi yang dinamis menimbulkan tantangan besar dalam pelaksanaan pengenalan citra. Dalam paper ini, kami menggunakan korelasi inheren antara deteksi dan kalibrasi untuk meningkatkan kinerja menggunakan MTCNN (Multi-task Cascaded Convolutional Neural Network) Selain itu, kami memanfaatkan kerangka Google FaceNet untuk mempelajari pemetaan dari gambar wajah ke ruang Euclidean yang ringkas, di mana jarak secara langsung sesuai dengan ukuran kesamaan wajah untuk mengekstraksi kinerja algoritma fitur wajah.

Tabel 1. Function loadLabeledImages()

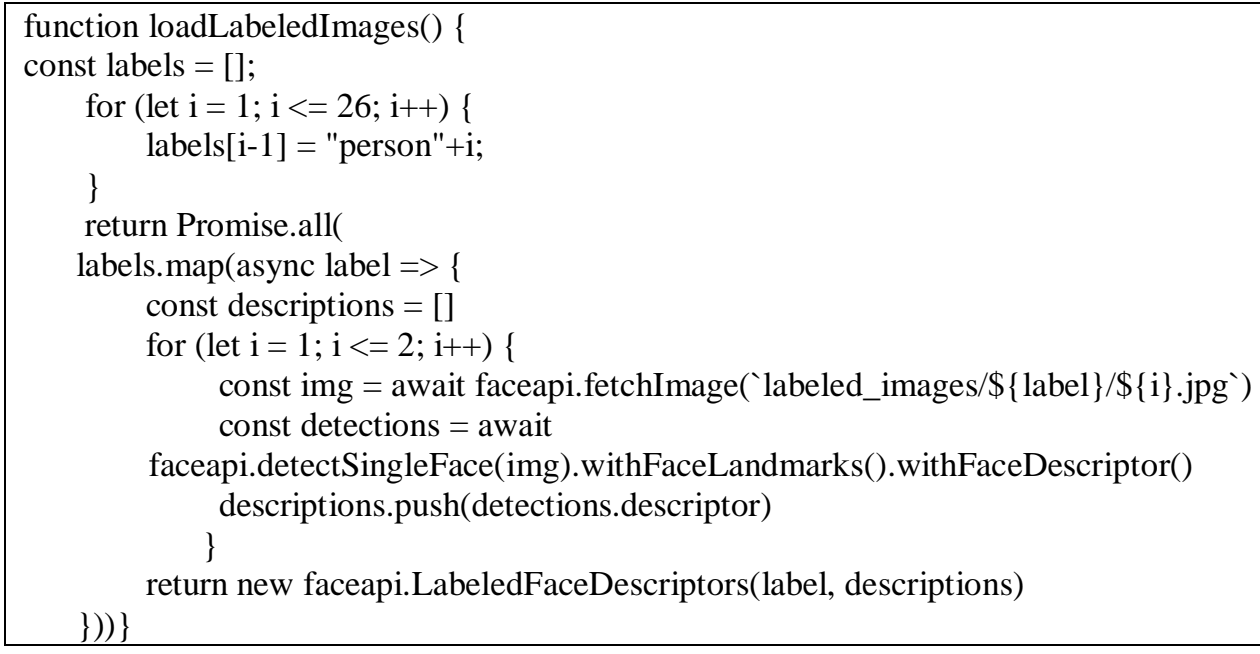

Tabel 1 di atas merupakan sebuah method yang bernama function loadLabeledImages(), fungsi tersebut merupakan fungsi yang khusus mengerjakan pekerjaan load label image. Pekerjaan Load label image ini dilakukan untuk 
mengambil nilai label iamge sebagai data identitas image yang diujikan menggunakan MTCNN (Multi-task Cascaded Convolutional Neural Network).

Tabel 2. Library Face API dengan MTCNN

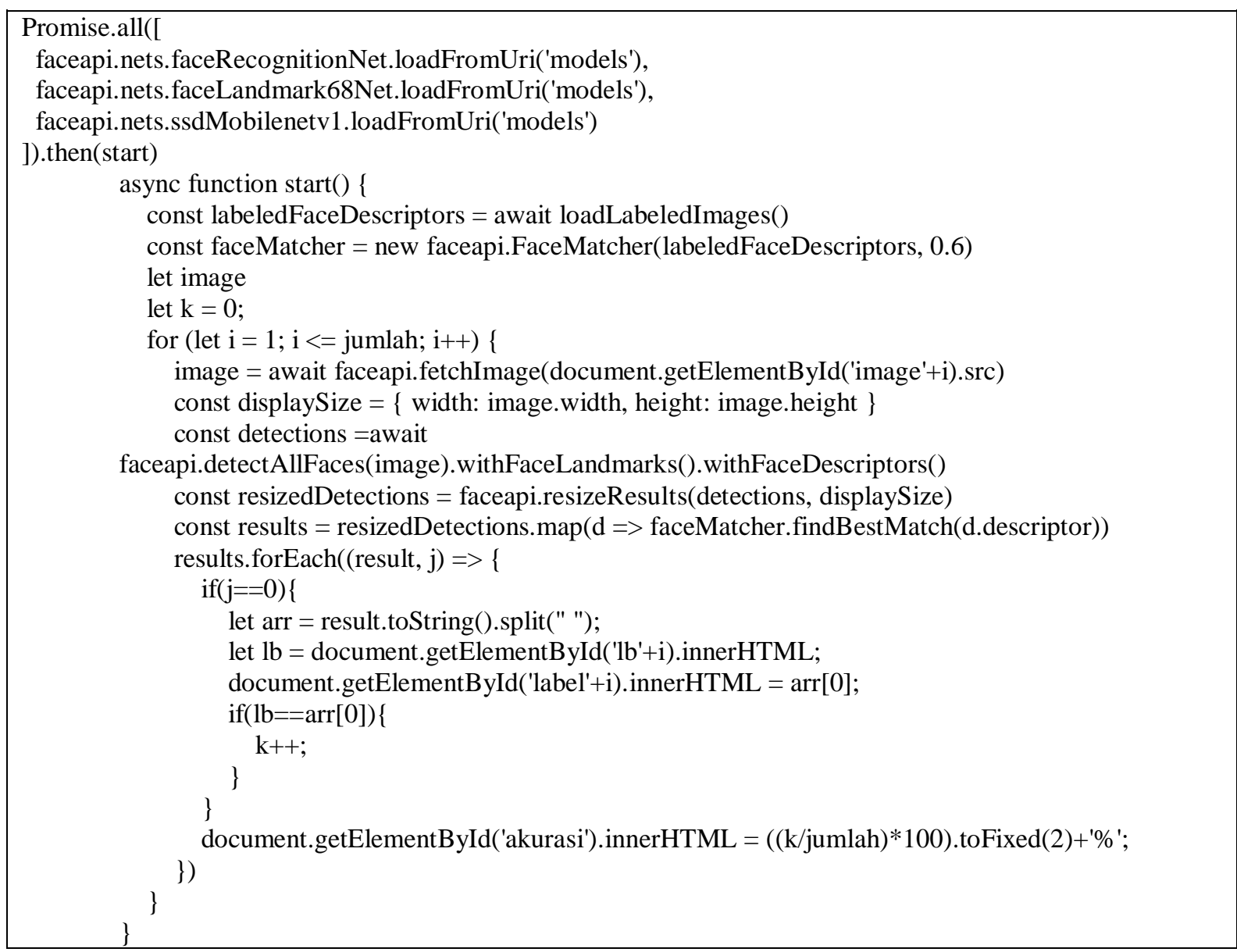

Tabel 2 di atas merupakan kode program inisialisasi API pengenalan wajah dengan menggunakan algoritma MTCNN (Multi-task Cascaded Convolutional Neural Network). Terdapat variabel yang bernama labeledFaceDescriptors, variabel tersebut merupakan variabel penampung fitur wajah yang diuji. Kemudian terdapat pula variabel faceMatcher yang khusus menampung hasil pencocokan wajah yang diuji dengan fitur data wajah yang di-training. Pekerjaan pendeteksian citra wajah dilakukan oleh fungsi detectAllFaces. Pekerjaan deteksi objek wajah ini dilakukan dengan mencari daerah ROI (region of Interest) pada seluruh nilai piksel citra yang dimasukkan. Jika ditemukan nilai ROI wajah pada citra yang diperiksa maka objek ditemukan, lalu dicocokan dengan nilai fitur yang sudah disimpan untuk dikenali pemiliknya. Hal tersebut dilakukan untuk mengambil nilai label citra sebagai data identitas citra yang diujikan menggunakan MTCNN (Multi-task Cascaded Convolutional Neural Network). Untuk pekerjaan pengecekan kecocokan citra wajah yang diuji dengan citra wajah yang dilatih dengan inputan yang berbeda, digunakan pengukuran jarak Euclidean distance.

\subsection{Pengembangan Sistem Pengenalan Wajah dengan MTCNN}

Bagian ini dilakukan pengembangan sistem yang digunakan untuk melakukan eksperimen riset menggunakan algoritma MTCNN (Multi-task Cascaded Convolutional Neural Network) untuk pengenalan wajah. Sitem yang dikembangkan dalam penelitian ini menggunakan Bahasa pemrograman javascript. Pemilihan Bahasa pemrograman ini didasarkan pada tujuan pemanfaatan dari hasil penelitian pengenalan wajah dengan menggunakan algoritma MTCNN (Multi-task Cascaded Convolutional Neural Network) akan diterapkan apada sistem absensi berbasis mobile.

\subsection{Evaluasi Pengenalan Wajah dengan MTCNN}

Untuk evaluasi eksperimen riset menggunakan algoritma MTCNN (Multi-task Cascaded Convolutional Neural Network) untuk pengenalan wajah dalam penelitian ini, digunakan sistem akurasi. Dimana nilai akurasi adalah nilai dari citra yang berhasil dikenali dibagi dengan seluruh citra yang diuji. Kami juga melakukan evaluasi kcross validation. 


\section{ANALISA DAN PEMBAHASAN}

\subsection{Analisis Eksperimen Pengenalan Wajah dengan Algoritma MTCNN}

Bagian ini dilakukan pengujian data citra dari dataset Aberdeen menggunakan algoritma MTCNN (Multi-task Cascaded Convolutional Neural Network) untuk pengenalan wajah dalam penelitian ini. Terdapat 60 citra dari dataset Aberdeen yang digunakan dari 30 wajah orang yang berbeda. Variasi setiap satu wajah manusia yang digunakan adalah dua variasi arah yang di ambil secara bebas dari berbagai tempat sehingga citra yang dihaslkan dapat terpengaruh berbagai ariasi pencahayaan, variasi ukuran wajah, serta variasi arah pengambilan. Untuk sementra pengujian dilakukan dengan pelabelan dummy, di mana setiap orang dilabekan person1, person2 dan seterusnya. Berikut ini adalah hasil cuplikan dari hasil pengujian yang dilakukan secara otomatis menggunakan sistem riset yang kami banging menggunakan library API pengenalan wajah menggunakan MTCNN (Multi-task Cascaded Convolutional Neural Network) dengan menggunakan bahasa pemrograman Javascript.

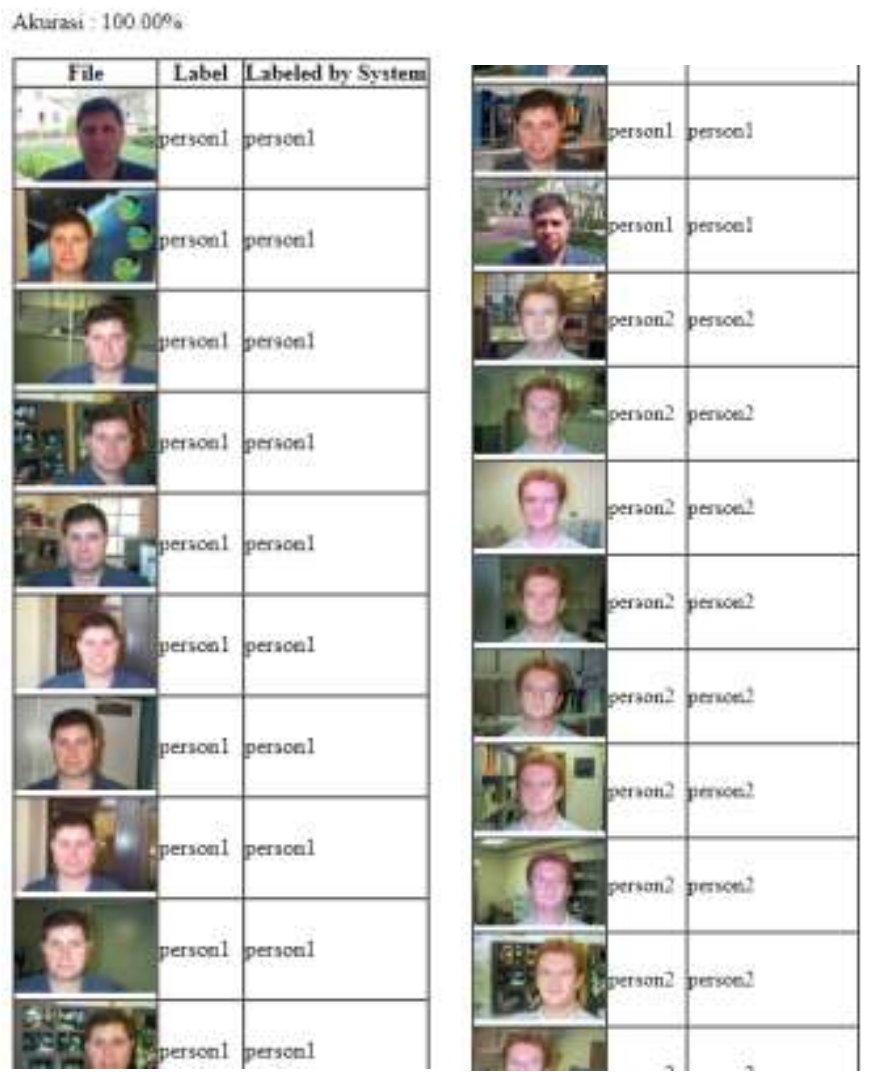

Gambar 1. Tampilan Hasil Pengujian Citra Wajah Yang Digunakan Dalam Berbagai Arah

Gambar 1 adalah cuplikan hasil dari hasil pengujian yang dilakukan secara otomatis menggunakan sistem riset yang kami bangun menggunakan library API pengenalan wajah menggunakan MTCNN (Multi-task Cascaded Convolutional Neural Network) dengan menggunakan bahasa pemrograman Javascript. Tampilan hasil pengujian citra wajah yang digunakan dalam berbagai arah.Dari hasil pengujian yang dilakukan dapat dilihat bahwa dengan ekspresi wajah yang berbeda, dengan arah sudut pandang pengambilan yang berbeda sistem dapat menemukan label yang diujikan sesuai dengan data citra wajah yang sudah dilatih. 

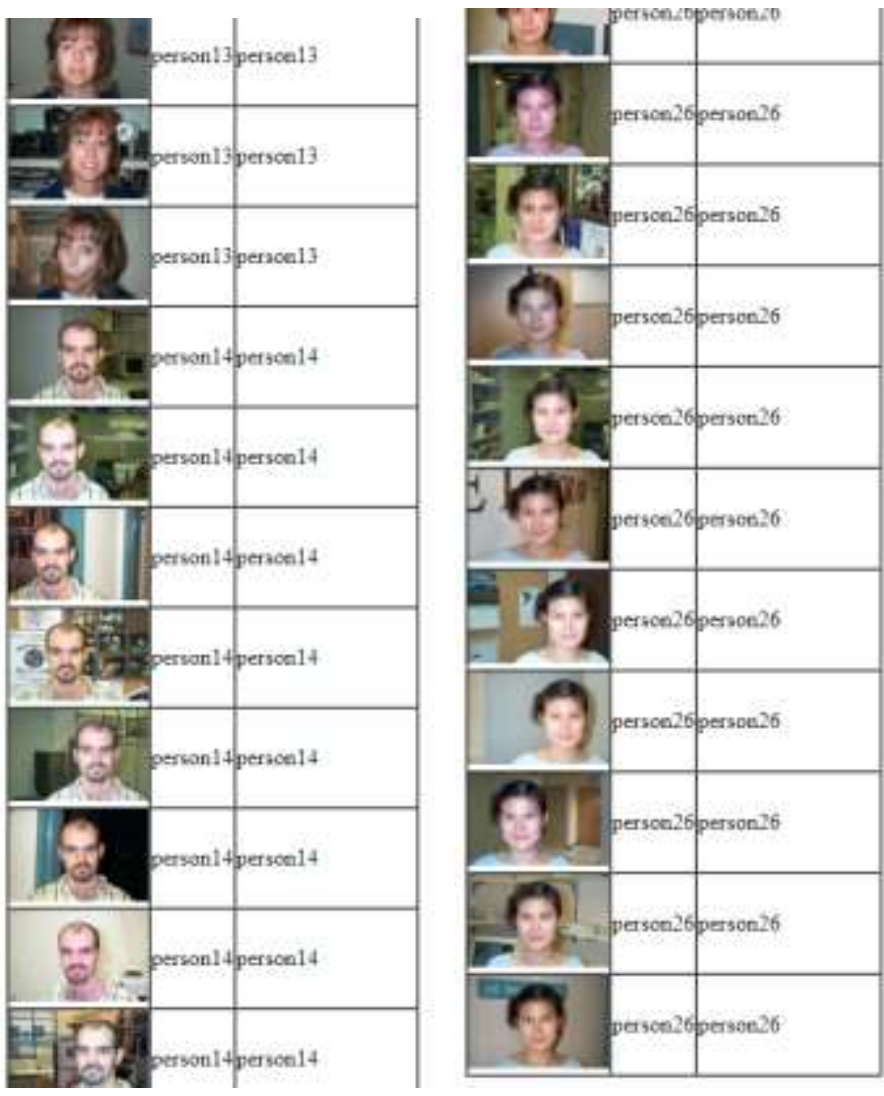

Gambar 2. Tampilan Hasil Pengujian Citra Wajah Yang Digunakan Dalam Berbagai Variasi Pencahayaan dan Ekspresi

Gambar 2 adalah cuplikan hasil dari hasil pengujian yang dilakukan secara otomatis menggunakan sistem riset yang kami bangun menggunakan library API pengenalan wajah menggunakan MTCNN (Multi-task Cascaded Convolutional Neural Network) dengan menggunakan bahasa pemrograman Javascript. Tampilan hasil pengujian citra wajah yang digunakan dalam berbagai variasi pencahayaan dan ekspresi. Dari hasil pengujian yang dilakukan dapat dilihat bahwa dengan ekspresi wajah yang berbeda, dengan arah sudut pandang pengambilan yang berbeda sistem dapat menemukan label yang diujikan sesuai dengan data citra wajah yang sudah dilatih.

\section{IMPLEMENTASI}

\subsection{Analisis Citra Pengujian Dan Hasil Pengenalan MTCNN}

Pada bagian ini ditampilkan beberapa model variasi pengujian cira Aberdeen yang digunakan pada sistem riset pengenalan wajah menggunakan MTCNN (Multi-task Cascaded Convolutional Neural Network). Pada dataset citra yang digunakan terdapat variasi pencahayaan (gelap, terang, sedang). Variasi ini adalah variasi alami yang dihasilkan saat pengambilan gambar yang dilakukan secara random baik saat berada di dalam ruang, di luar ruang ataupun pada tempat yang teduh namun latar terang. Variasi lainnya adalah posisi objek yang terdapat pada dataset Aberdeen, antara lain bisa saja diambil dari dekat wajah, dari jauh dengan kemiringan yang berbeda-beda. Bisa saja wajah yang diambil sedang agak menunduk, miring, menengadah dan variasi kemiringan sudut pandang yang sangat variatif. Selain itu, ekspresi wajah pada citra objek juga sangat beragam. Variasi berbagai ekspresi seperti marah, sedih, kesal, senyum, datar, mengernyit juga tetap diolah dalam pengujian pada sistem riset ini. 


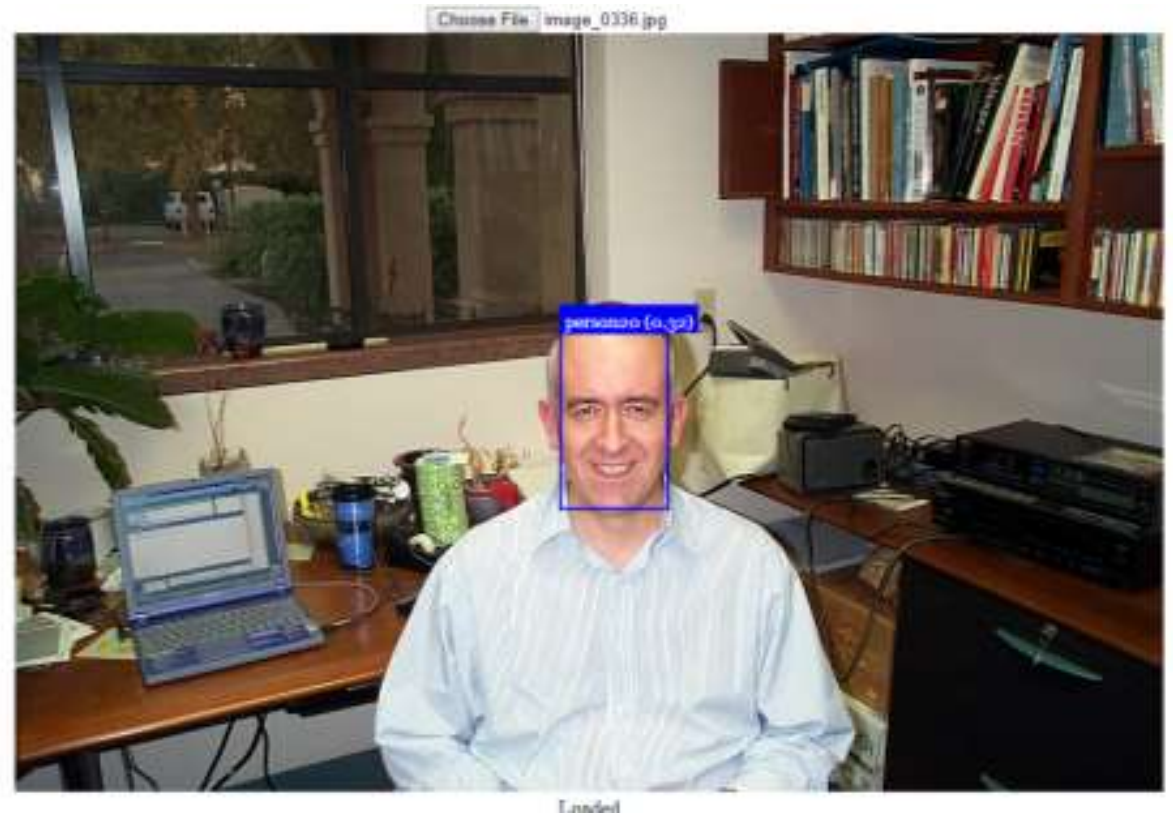

Gambar 3. Contoh Citra Pengujian Dengan Variasi Pencahayaan Terang, Posisi Jauh dan Ekspresi Tersenyum

Gambar 3 adalah contoh citra dengan variasi pencahayaan terang, posisi jauh dan ekspresi tersenyum cuplikan hasil dari hasil pengujian yang dilakukan secara otomatis menggunakan sistem riset yang kami bangun menggunakan library API pengenalan wajah menggunakan MTCNN (Multi-task Cascaded Convolutional Neural Network) dengan menggunakan bahasa pemrograman Javascript. Pada sistem ditampilkan contoh citra dapat dikenali sebagai person20 dengan jarak kedekatan hasil pengukuran eulidean distance sebesar 0.32. Berarti jarak kedekatan antara citra uji dan citra latih sangat mendekati fitur pada person 20.

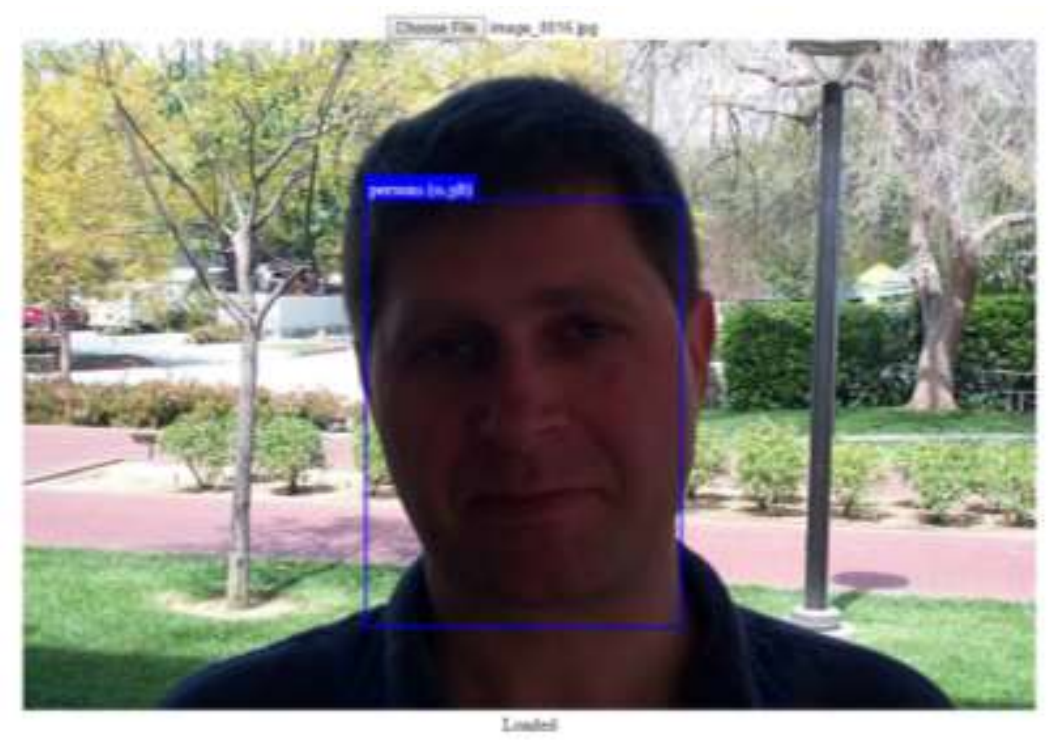

Gambar 4. Contoh Citra Pengujian Dengan Variasi Pencahayaan Gelap Dan Posisi Di Tengah Serta Dengan Kemiringan Posisi Serta Ekspresi Sedih

Gambar 4 adalah contoh citra pengujian dengan variasi pencahayaan gelap dan posisi di tengah serta dengan kemiringan posisi serta ekspresi sedih cuplikan hasil dari hasil pengujian yang dilakukan secara otomatis menggunakan sistem riset yang kami bangun menggunakan library API pengenalan wajah menggunakan MTCNN (Multi-task Cascaded Convolutional Neural Network) dengan menggunakan bahasa pemrograman Javascript. Pada sistem ditampilkan contoh citra dapat dikenali sebagai person20 dengan jarak kedekatan hasil pengukuran eulidean distance sebesar 0.38. Berarti jarak kedekatan antara citra uji dan citra latih sangat mendekati fitur pada person01. 


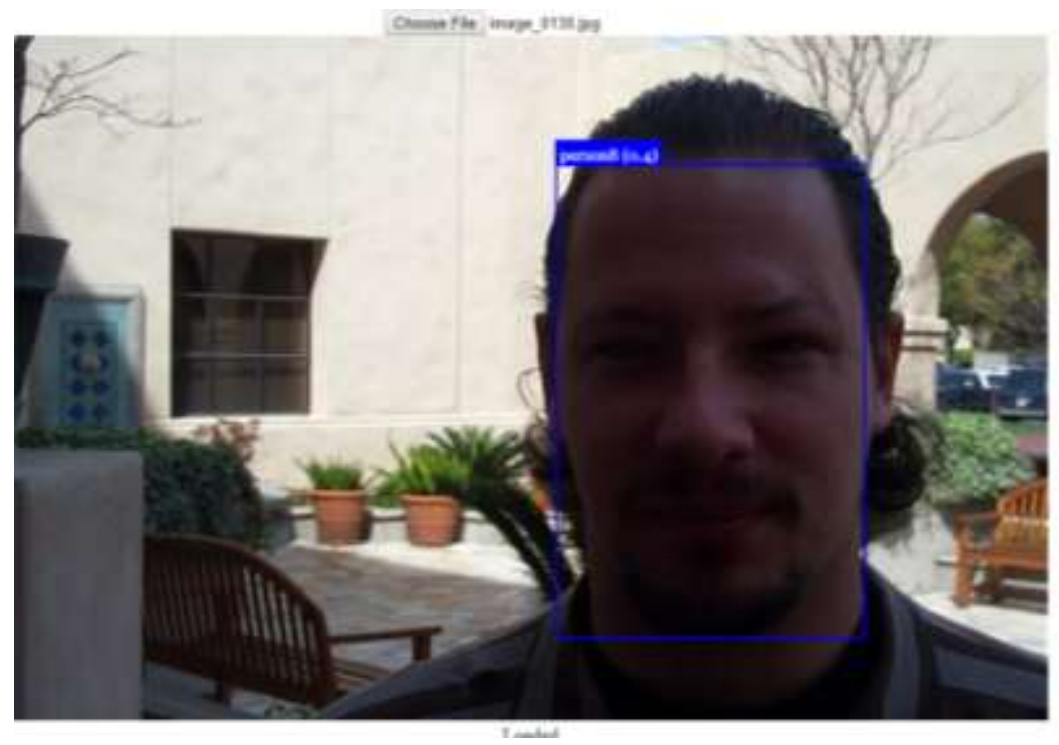

Gambar 5. Contoh Citra Pengujian Dengan Variasi Pencahayaan Gelap Dan Posisi Tidak Di Tengah Serta Ekspresi Datar

Gambar 5 adalah contoh citra pengujian dengan variasi pencahayaan gelap dan posisi tidak di tengah serta ekspresi datar cuplikan hasil dari hasil pengujian yang dilakukan secara otomatis menggunakan sistem riset yang kami bangun menggunakan library API pengenalan wajah menggunakan MTCNN (Multi-task Cascaded Convolutional Neural Network) dengan menggunakan bahasa pemrograman Javascript. Pada sistem ditampilkan contoh citra dapat dikenali sebagai person20 dengan jarak kedekatan hasil pengukuran eulidean distance sebesar 0.34. Berarti jarak kedekatan antara citra uji dan citra latih sangat mendekati fitur pada person08.

Dari contoh pengujian yang disajikan dari variasi citra uji dan latih dapat dilihat bahwa sistem riset pengenalan wajah menggunakan MTCNN (Multi-task Cascaded Convolutional Neural Network) sangat baik dalam mengenal citra wajah dalam berbagai kondisi. Hasil ini sangat ideal jika fitur pengenalan wajah ini dijadikan sebagai fitur absens yang digunakan secara mobile seperti sistem pelaporan kinerja sales dan marketing ataupun anggota personil kepolisian yang biasa bekerja secara mobile.

\section{KESIMPULAN}

Dari hasil pengujian yang dilakukan secara otomatis menggunakan beberapa model variasi pengujian citra dataset Aberdeen sebanyak 60 citra dari 30 orang berbeda yang digunakan pada sistem riset pengenalan wajah menggunakan MTCNN (Multi-task Cascaded Convolutional Neural Network) dihasilkan kesimpulan. Beberapa parameter citra yang mempengaruhi seperti variasi pencahayaan (gelap, terang, sedang), variasi posisi objek (antara lain bisa saja diambil dari dekat wajah, dari jauh dengan kemiringan yang berbeda-beda), kemudian posisi yang diambil (agak menunduk, miring, menengadah dan variasi kemiringan sudut pandang yang sangat variatif), selain itu, ekspresi wajah pada citra objek yang sangat beragam (marah, sedih, kesal, senyum, datar, mengernyit), sistem riset pengenalan wajah pengenalan wajah menggunakan MTCNN (Multi-task Cascaded Convolutional Neural Network) berhasil melakukan pengenalan wajah sebesar 100\%. Dengan demikian, nilai true positive berjumlah sama dengan jumlah data yang dites dan nilai true negative berjumlah nol

\section{REFERENCES}

[1] I. Supriana and Y. Pratama, "Face recognition new approach based on gradation contour of face color," Int. J. Electr. Eng. Informatics, vol. 9, no. 1, pp. 125-138, 2017.

[2] R. Ranjan, V. M. Patel, and R. Chellappa, "A deep pyramid Deformable Part Model for face detection," 2015 IEEE 7th Int. Conf. Biometrics Theory, Appl. Syst. BTAS 2015, 2015.

[3] Saparudin and E. Rasywir, "Pengenalan potensi anak melalui sidik jari menggunakan algoritma voting feature intervals 5 (vfi5) 1 ," vol. I, no. I, pp. 25-30, 2012.

[4] T. S. Chan and A. Kumar, "Reliable ear identification using 2-D quadrature filters," Pattern Recognit. Lett., vol. 33, no. 14, pp. 1870$1881,2012$.

[5] Fachruddin, E. Rasywir, Hendrawan, Y. Pratama, D. Kisbianty, and M. R. Borroek, "Real Time Detection on Face Side Image with Ear Biometric Imaging Using Integral Image and Haar- Like Feature,” 2018 Int. Conf. Electr. Eng. Comput. Sci., pp. 165-170, 2018.

[6] Y. Pratama and E. Rasywir, "Automatic Cost Estimation Analysis on Datawarehouse Project with Modified Analogy Based Method," in Proceedings of 2018 International Conference on Electrical Engineering and Computer Science, ICECOS 2018, 2019, pp. 171-176. 
JURNAL MEDIA INFORMATIKA BUDIDARMA, Vol 3, No 3, Juli 2019

ISSN 2614-5278 (media cetak)

ISSN 2548-8368 (media online)

Hal 240-247 | DOI: 10.30865/mib.v3i3.1324

[7] Y. Zhang and Z. Mu, "Ear detection under uncontrolled conditions with multiple scale faster Region-based convolutional neural networks," Symmetry (Basel)., vol. 9, no. 4, 2017.

[8] A. D. Egorov, A. N. Shtanko, and P. E. Minin, "Selection of Viola-Jones algorithm parameters for specific conditions," Bull. Lebedev Phys. Inst., vol. 42, no. 8, pp. 244-248, 2015.

[9] J. W. Yodha and A. W. Kurniawan, "Pengenalan Motif Batik Menggunakan Deteksi Tepi Canny Dan K-Nearest Neighbor," Techno.COM, vol. 13, no. 4, November, pp. 251-262, 2014.

[10] B. P. S. S. Ashish Mohan Yadav, "A Survey On: 'Content Based Image Retrieval Systems,"” Int. J. Emerg. Technol. Adv. Eng., vol. 4, no. 6, pp. 22-26, 2014

[11] S. R. Dubey, S. K. Singh, and R. K. Singh, "Multichannel decoded local binary patterns for content-based image retrieval," IEEE Trans. Image Process., vol. 25, no. 9, pp. 4018-4032, 2016.

[12] P. Liu, J. M. Guo, C. Y. Wu, and D. Cai, "Fusion of deep learning and compressed domain features for content-based image retrieval," IEEE Trans. Image Process., vol. 26, no. 12, pp. 5706-5717, 2017.

[13] P. S. J. Durai Raj and G. W. Jiji, "Content-based image retrieval in dermatology using intelligent technique," IET Image Process., vol. 9, no. 4, pp. 306-317, 2015. 